\title{
НОВЫЕ ДАННЫЕ О МИНЕРАЛАХ. \\ ВЫПУСК 4. ПЕРВЫЕ НАХОДКИ В РОССИИ И В КОЛЬСКОМ РЕГИОНЕ
}

\section{Волошин А.В., Карпов С.М., Чернявский А.В., Компанченко А.А.} Геологический институт КНЦ РАН, Anamumbl,vol@geoksc.apatity.ru

Одним из важнейших показателей развития минералогии в регионе, является количество открываемых новых минералов [2]. Ежегодно мы представляем сводку о результатах исследования минералогии уникальных объектов Кольского региона, где приводятся краткие сведения о морфологии, ассоциации и конституционных параметрах новых для региона и России минеральных видов.

Геологическими объектами данного выпуска явились: кварц - карбонатные $\mathrm{Pb}-\mathrm{Zn}$ жилы Мypманского побережья, участок Самуил; серно-колчеданное проявление Брагино, Южная Печенга; редкометалльные пегматиты месторождения Васин-Мыльк, Вороньи тундры и щелочные метасоматиты участка Доломитовый карьер, Южное Прихибинье, ИВСЗ (рис. 1).

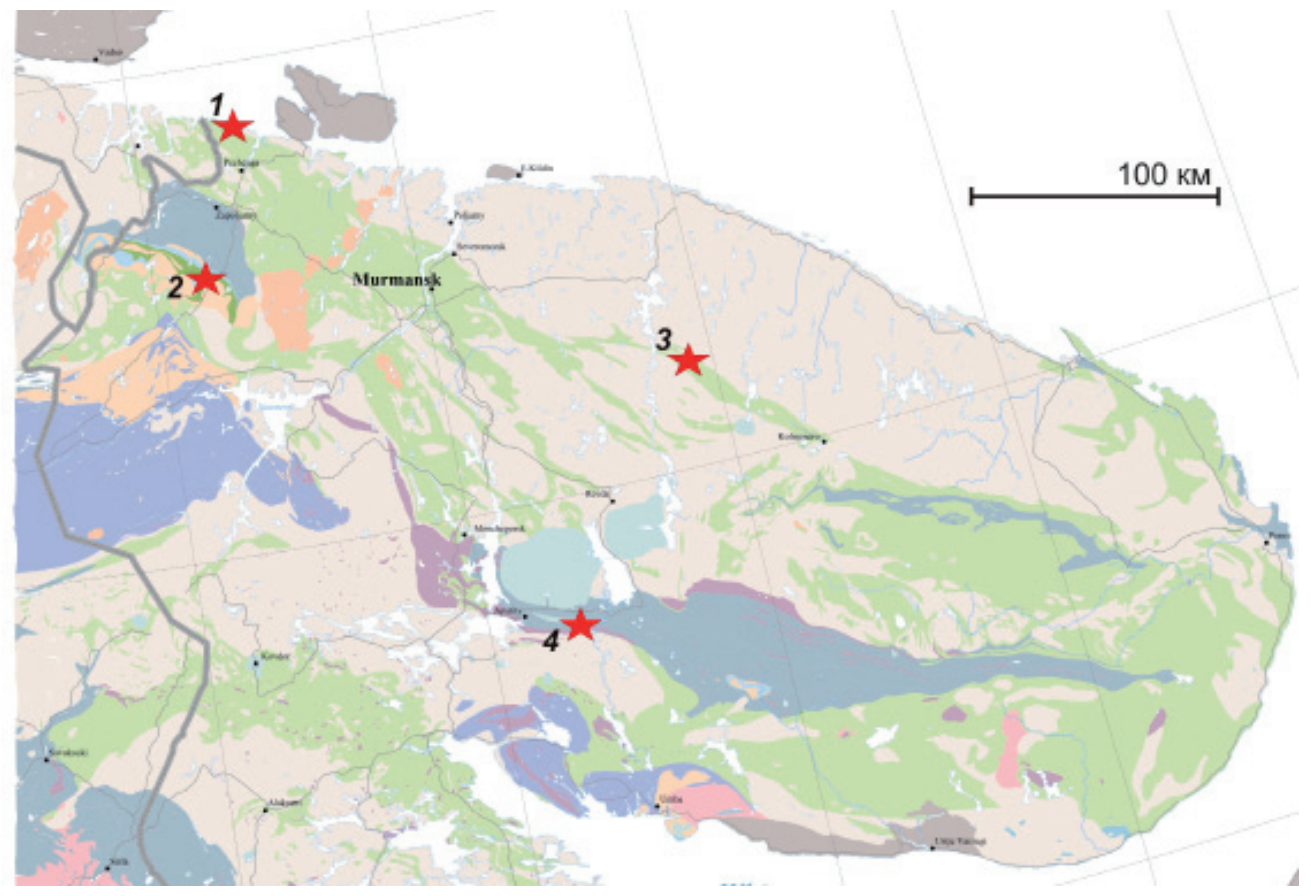

Рис. 1. Обзорная геологическая карта Кольского региона с объектами исследований:

1 - участок Самуил; 2 - проявление Брагино; 3 - месторождение Васин-Мыльк; 4 - Доломитовый карьер.

Изучение минеральных объектов проводилось на оптическом микроскопе Axioplan в отраженном и проходящем поляризованном свете с блоком видиорегистрации. Исследование фазовой и внутрифазовой неоднородности минералов осуществлялась при помощи сканирующего электронного микроскопа LEO-1450 с оценкой состава минеральных фаз с использованием спектрометра Bruker X Flash-5010 и JXA-8230 (Jeol). Химический анализ однородных зёрен минеральных фаз размером более 20 мкм выполнен на электронно-зондовом микроанализаторе Cameca MS-46. Рентгеновская диагностика проводилась на рентгеновский дифрактометре ДРОН-2, камера РКД 57.3 мм при $\mathrm{Fe} K_{\alpha}$ - излучении. Исследования минералов методом комбинационного рассеяния (КР) проводились на раман-спектрометрах Almega XR ThermoScientific, микроскоп Olympus BX51, объектив 100x, лазер 532 нм в Институте геологии КарНЦ РАН, Петрозаводск и HORIBA Jobin-Yvon LabramHR800, лазер 488, 514 нм, ресурсный центр СПбГУ «Геомодель», Санкт-Петербург.

\section{Результаты изучения минералов}

Результатом выполненных минералогических исследований явилось установление минералов, впервые найденных в России и Кольском регионе относимых в классам карбонатов, сульфатов, 
ванадатов, островных и цепочечных силикатов, органических минералов (табл. 1). В таблице 2 приведены данные по методам диагностики, подтверждающим достоверность отнесения минеральной фазы к тому или иному минеральному виду.

Таблица 1. Новые минералы Кольского региона и России.

\begin{tabular}{|c|c|c|}
\hline Минерал & Формула & География, геология \\
\hline \multicolumn{3}{|c|}{ Карбонатьл } \\
\hline Гидроцинкит & $\mathrm{Zn}_{5}\left(\mathrm{CO}_{3}\right)_{2}(\mathrm{OH})_{6}$ & $\begin{array}{l}\text { Мурманское побережье, кварц-карбонатные } \\
\text { жилы, участок Самуил }\end{array}$ \\
\hline Аурихальцит & $(\mathrm{Zn}, \mathrm{Cu})_{5}\left(\mathrm{CO}_{3}\right)_{2}(\mathrm{OH})_{6}$ & То же \\
\hline \multicolumn{3}{|c|}{ Сульфатьл } \\
\hline Лангит & $\mathrm{Cu}_{4}\left(\mathrm{SO}_{4}\right)(\mathrm{OH})_{6} \cdot 2 \mathrm{H}_{2} \mathrm{O}$ & $\begin{array}{l}\text { Мурманское побережье, кварц-карбонатные } \\
\text { жилы, участок Самуил }\end{array}$ \\
\hline \multicolumn{3}{|c|}{ Ванадаты } \\
\hline Уэкфилдит-(Се) & $(\mathrm{Ce}, \mathrm{La}, \mathrm{Nd}, \mathrm{Pb}) \mathrm{VO}_{4}$ & $\begin{array}{l}\text { Южное Прихибинье, Доломитовый карьер, } \\
\text { щелочные метасоматиты }\end{array}$ \\
\hline \multicolumn{3}{|l|}{ Силикаты } \\
\hline Гафнон & $\mathrm{Hf}\left(\mathrm{SiO}_{4}\right)$ & $\begin{array}{l}\text { Вороньи тундры, редкометалльные пегматиты, } \\
\text { месторождение Васин-мыльк }\end{array}$ \\
\hline Джервисит & $\mathrm{NaSc}\left(\mathrm{Si}_{2} \mathrm{O}_{6}\right)$ & $\begin{array}{l}\text { Южная Печенга, рудопроявление Брагино, } \\
\text { колчеданные (пирротиновые) руды }\end{array}$ \\
\hline \multicolumn{3}{|c|}{ Органические минераль } \\
\hline Мулуит & $\mathrm{CuC}_{2} \mathrm{O}_{4} \cdot \mathrm{nH}_{2} \mathrm{O}$ & $\begin{array}{l}\text { Мурманское побережье, кварц-карбонатные } \\
\text { жилы, участок Самуил }\end{array}$ \\
\hline Уэдделлит & $\mathrm{CaC}_{2} \mathrm{O}_{4} \cdot 2 \mathrm{H}_{2} \mathrm{O}$ & То же \\
\hline
\end{tabular}

Примечание. жирным шрифтом отмечены минералы, впервые установленные в России

Таблица 2. Достоверность минерального вида. Методы диагностики.

\begin{tabular}{|c|c|c|c|c|c|}
\hline \multirow[b]{2}{*}{ Минерал } & \multirow[b]{2}{*}{ Формула } & \multicolumn{2}{|c|}{ Химический состав } & \multicolumn{2}{|c|}{ Крист. структура } \\
\hline & & $\begin{array}{l}\text { Leo-1450, } \\
\text { JXA-8230 (Jeol) }\end{array}$ & $\begin{array}{l}\text { Cameca } \\
\text { MS-46 }\end{array}$ & $\mathbf{P \Phi} \mathbf{A}^{*}$ & PC \\
\hline Гафнон & $\mathrm{Hf}\left(\mathrm{SiO}_{4}\right)$ & + & + & & + \\
\hline Джервисит & $\operatorname{NaSc}\left(\mathrm{Si}_{2} \mathrm{O}_{6}\right)$ & + & & & + \\
\hline Уэкфилдит-(Cе) & $(\mathrm{Ce}, \mathrm{La}, \mathrm{Nd}, \mathrm{Pb}) \mathrm{VO}_{4}$ & + & & & + \\
\hline Гидроцинкит & $\mathrm{Zn}_{5}\left(\mathrm{CO}_{3}\right)_{2}(\mathrm{OH})_{6}$ & & & + & \\
\hline Аурихальцит & $(\mathrm{Zn}, \mathrm{Cu})_{5}\left(\mathrm{CO}_{3}\right)_{2}(\mathrm{OH})_{6}$ & & & + & \\
\hline Лангит & $\mathrm{Cu}_{4}\left(\mathrm{SO}_{4}\right)(\mathrm{OH})_{6} \cdot 2 \mathrm{H}_{2} \mathrm{O}$ & & & + & \\
\hline Мулуит & $\mathrm{CuC}_{2} \mathrm{O}_{4} \cdot \mathrm{nH}_{2} \mathrm{O}$ & & & + & \\
\hline Уэдделлит & $\mathrm{CaC}_{2} \mathrm{O}_{4} \cdot 2 \mathrm{H}_{2} \mathrm{O}$ & & & + & \\
\hline
\end{tabular}

Примечание. РФА - рентгено-фазовый анализ, РС - рамановская спектроскопия.

Аналитики: химический состав - Е.Э. Савченко, А.А. Тележкин, А.В. Базай (все ГИ КНЦ РАН), Галанкина О.Л. (ИГД РАН); рентгено-фазовый анализ - Е.А. Селиванова, М.Ю. Рауд; рамановская спектроскопия - оператор В.Н. Бочаров.

Гафнон $\boldsymbol{H} f\left(\mathrm{SiO}_{4}\right)$. В интерактивных минералогических базах и справочниках приведена информация о трех полях редкометалльных пегматитов, в которых установлен гафнон как собственный минеральный вид: Мозамбик, месторождение Муяне [4]; Китай, Монгольский Алтай, месторождение Коктогай [6]. Начало истории этого минерала на Кольском регионе начинается с 1976 г. При документации шурфов на месторождении в участках развития лепидолитового грейзена был обнаружен необычный минерал, по данным РФА имеющего структуру циркона. По данным рентгено-спектрального локального анализа циркон характеризуется высоким аномальным содержанием гафния. Высокогафниевый циркон находятся в тесной ассоциации с холтитом и стибиотан- 

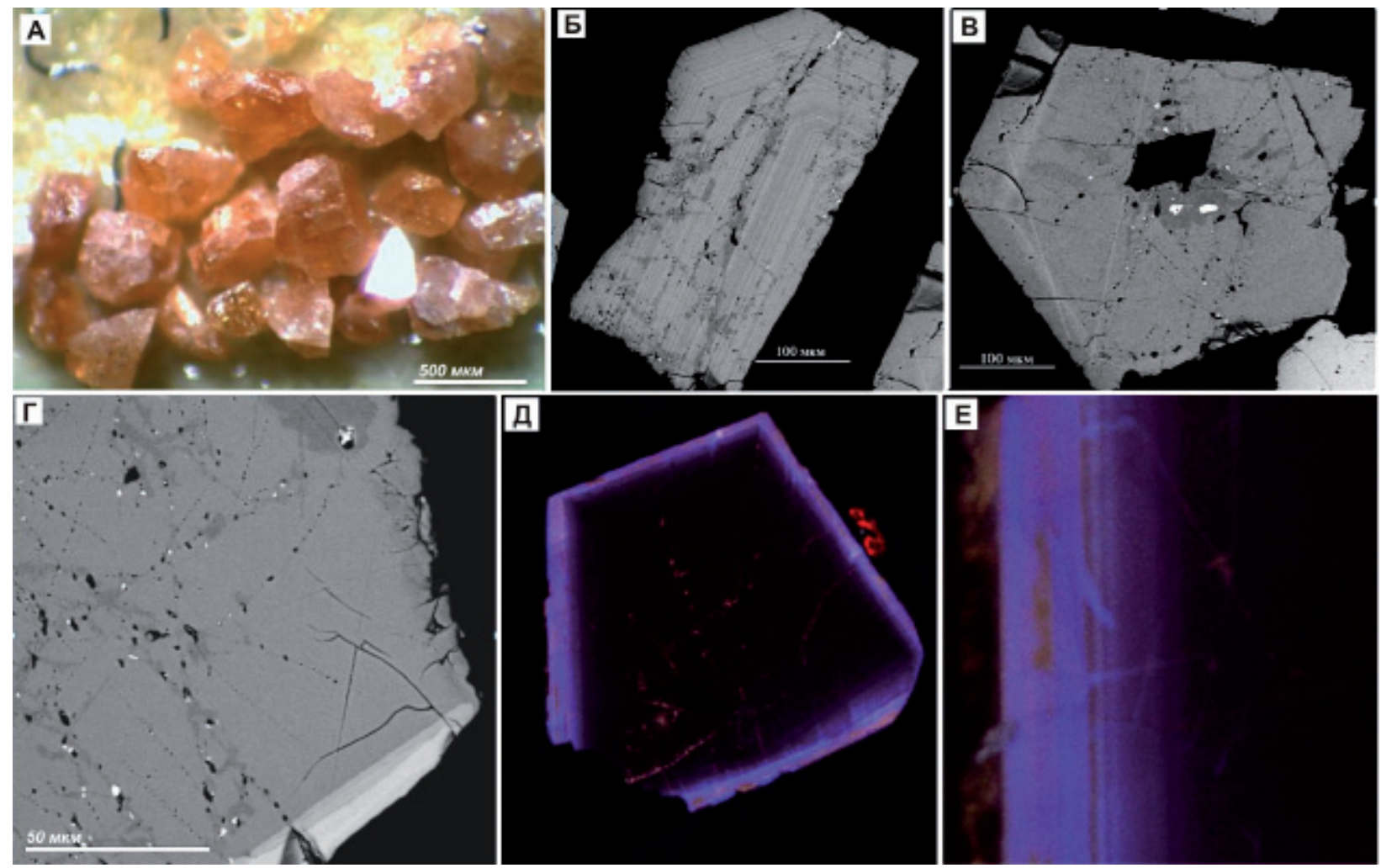

Рис. 2. Морфология кристаллов и внутренняя неоднородность индивидов высокогафниевого циркона и гафнона. А. - внешний вид кристаллов, снимок в косом освещении; Б - осциляторная зональность, снимок в обратно рассеянных электронах (BSE); В - неоднородность блочного типа, BSE; Г - фазовая неоднородность, снимок BSE; Д, Е - катодолюминесценция краевых зон в кристаллах - вторая генерация циркона и гафнон.

талитом, представляя собой идиоморфные, практически без трещин индивиды дипирамидального габитуса размером около 200-500 $\mu \mathrm{m}$ розовато-желтой и желто-оранжевой окраски (рис. 2, А).

Внутренне строение кристаллов неоднородное. Внутрифазовая неоднородность проявляется в виде осциляторной зональности во многих индивидах (рис. 2, Б), реже наблюдается слабо проявленная осциляторная зональностью в сочетании с неоднородностью блочного типа (рис. 2, В). Фазовая неоднородность кристаллов циркона проявлена в виде включений других минеральных фаз в объеме индивидов: альбита, поллуцита, микролита, стибиотанталита, соседкоита-ранкамаита и других фаз с неопределенным статусом минерального вида. Также к этому типу неоднородности следует отнести и вторую генерацию циркона и гафнона, нарастающих в виде краевой зоны (рис. 2, Г). Это хорошо проявлено на снимках в отраженных электронах и снимках полученных при облучении кристаллов катодными лучами (рис. 2, Д, Е).

Таблица 3. Химический состав гафнона, Кольский полуостров, мас. \%.

\begin{tabular}{|c|c|c|c|c|c|c|c|c|}
\hline \multirow{2}{*}{ Кристалл } & \multirow{2}{*}{ Анализ } & \multirow{2}{*}{$\mathrm{SiO}_{2}$} & \multirow{2}{*}{$\mathrm{ZrO}_{2}$} & \multirow{2}{*}{$\mathrm{HfO}_{2}$} & \multirow{2}{*}{$\mathrm{Ta}_{2} \mathrm{O}_{5}$} & \multirow{2}{*}{ Сумма } & \multicolumn{2}{|c|}{ apfu } \\
\hline & & & & & & & $\mathrm{Zr}$ & $\mathrm{Hf}$ \\
\hline \multirow[t]{2}{*}{ KV1-2 } & 24 WDS & 24.89 & 26.244 & 48.306 & 0.315 & 100.081 & 0.481 & 0.519 \\
\hline & 25 WDS & 24.773 & 26.188 & 48.274 & & 99.581 & 0.481 & 0.519 \\
\hline \multirow[t]{4}{*}{ KV1-2-1 } & 026 & 29.04 & 24.26 & 46.7 & & 100 & 0.470 & 0.530 \\
\hline & 027 & 29.05 & 23.81 & 47.14 & & 100 & 0.463 & 0.537 \\
\hline & 028 & 29.16 & 24.67 & 46.17 & & 100 & 0.477 & 0.523 \\
\hline & 029 & 28.94 & 25.37 & 45.69 & & 100 & 0.487 & 0.513 \\
\hline \multirow[t]{3}{*}{ KV1-5-3 } & 032 & 28.74 & 23.05 & 48.21 & & 100 & 0.450 & 0.550 \\
\hline & 033 & 28.85 & 24.26 & 46.89 & & 100 & 0.469 & 0.531 \\
\hline & 15 WDS & 24.774 & 26.622 & 47.36 & & 98.87 & 0.490 & 0.510 \\
\hline
\end{tabular}


Поскольку структурные параметры гафнона и циркона идентичны, главным критерием достоверности диагностики гафнона следует считать химический анализ индивида, в результате которого определяется доминантность Hf над Zr (apfu) в катионной позиции кристаллической структуры циркона (табл. 3).

Джервисит $\mathrm{NaScSi}_{2} \boldsymbol{O}_{6}$ В мире известны два месторождения, где достоверно установлен этот минерал: Дэдхорс Крик, Канада [5] и Бавено, Италия [3]. Нами впервые в России и Кольском регионе джервисит был установлен в серно-колчеданных рудах участка Брагино, ЮПСЗ. Натрий скандиевый пироксен приурочен к шлирообразным обособлениям крупнозернистых пиритов, среди средне- мелкозернистой пирротиновой массы. Внутри пиритовых шлиров наблюдаются многочисленные полиминеральные включения редких нетипичных для основной рудной массы минералов: сидерит, альбит, минералы группы кричтонита, кызылкумит, ферберит, шамозит и мелкие (первые мкм) выделения джервисита (рис. 3). Структурное состояние минерала было определено методом рамановской спектроскопии по зерну в ассоциации с сидеритом. В области средних и больших значений полосы отражений в целом соответствуют клинопироксену и близки к эгирину. Отсутствие характерных для цепных силикатов полос отвечающих за валентные колебания связей в тетраэдре $\mathrm{Si}-\mathrm{O}$ в области значений $\left(950 \mathrm{~cm}^{-1}-1050 \mathrm{~cm}^{-1}\right)$ связывается с более интенсивным отражением вмещающего сидерита. Поэтому эта часть спектра джервисита находится в области шума. Оценочный состав минерала удовлетворительно рассчитывается на 6 атомов кислорода и по доминированию в структурных позициях $\mathrm{Na}$ в M2 и Sc в M1 минерал относится к джервиситу.
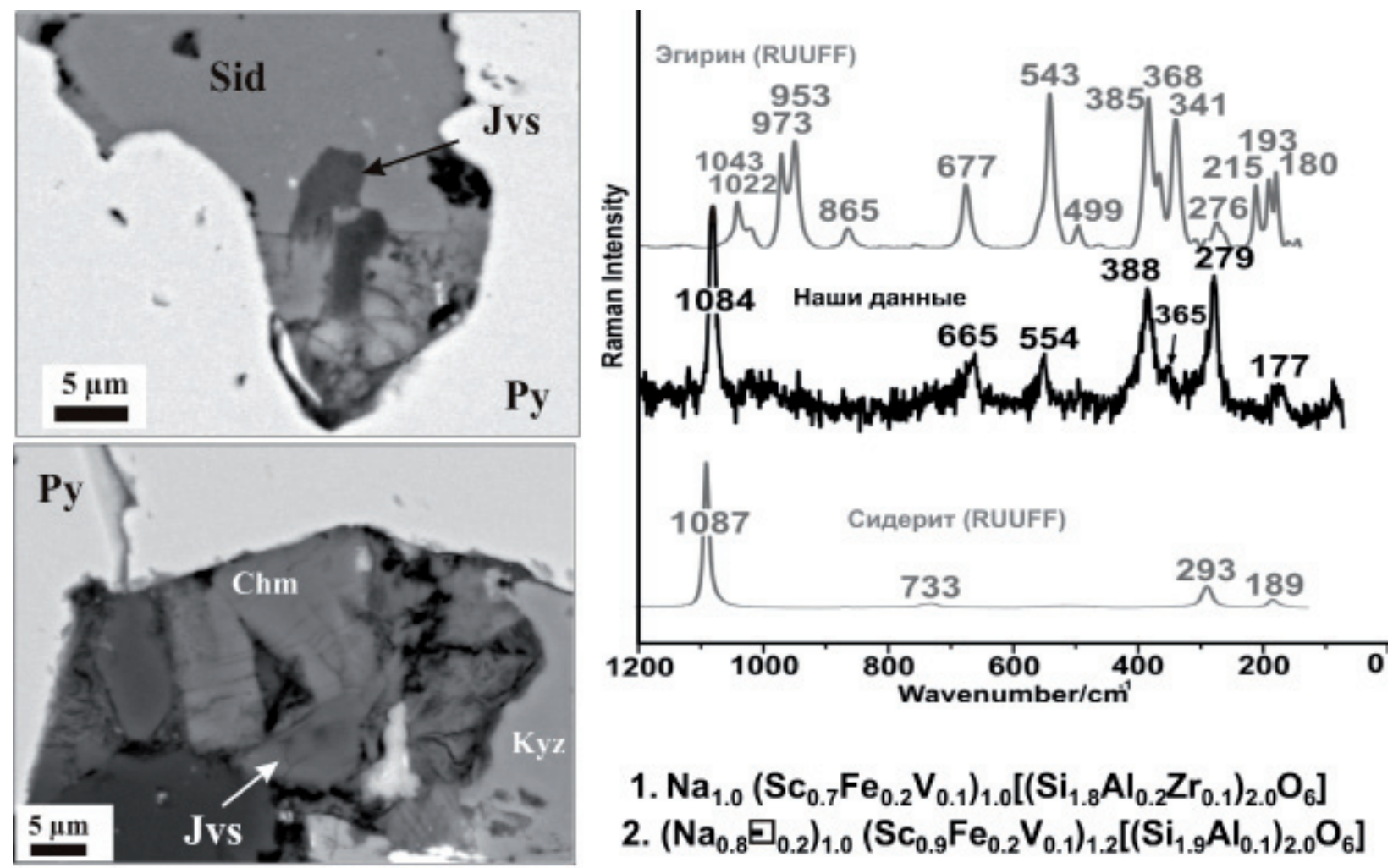

\section{1. $\mathrm{Na}_{1.0}\left(\mathrm{Sc}_{0.7} \mathrm{Fe}_{0.2} \mathrm{~V}_{0.1}\right)_{1.0}\left[\left(\mathrm{Si}_{1.8} \mathrm{Al}_{0.2} \mathrm{Zr}_{0.1}\right)_{2.0} \mathrm{O}_{6}\right]$ 2. $\left(\mathrm{Na}_{0.8} \Xi_{0.2}\right)_{1.0}\left(\mathrm{Sc}_{0.9} \mathrm{Fe}_{0.2} \mathrm{~V}_{0.1}\right)_{1.2}\left[\left(\mathrm{Si}_{1.9} \mathrm{AI}_{0.1}\right)_{2.0} \mathrm{O}_{6}\right]$}

Рис. 3. Характер выделений джервисита (Jvs) в пиритовых (Ру) обособлениях в рудах участка Брагино (справа - снимки BSE) и результаты исследования его конституции (слева - раманспектр и кристаллохимические формулы). Kуz - кызылкумит; Sid - сидерит; Chm - шамозит.

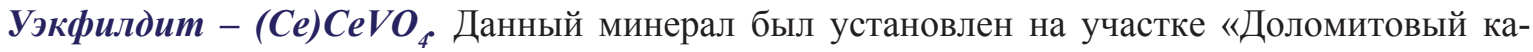
рьер» в образцах, отобранных из зоны контакта щелочных метасоматитов (фенитового состава) и окварцованных доломитов. В метасоматитах ранее нами были уставлены ванадиевые и ванадийсодержащие силикаты - наталлиит, вандиевый эгирин и магнезио-рибекит [1]. Уэкфилдит-(Се) находится в ассоциации с альбитом, апатитом, бастнезитом, иногда с повеллитом, другими ванадатами 


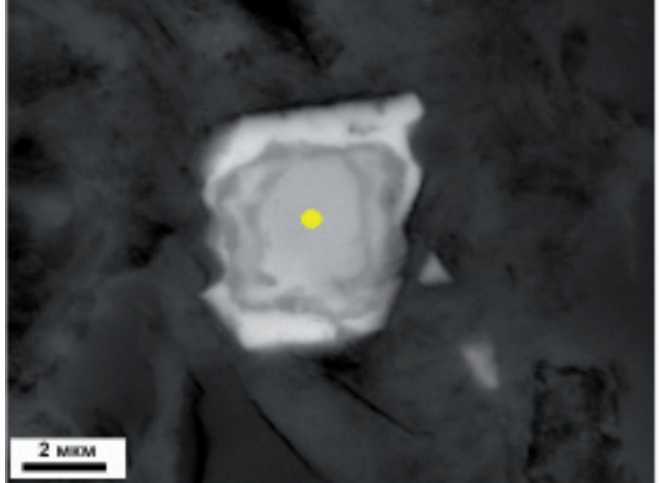

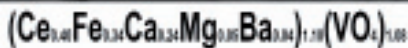

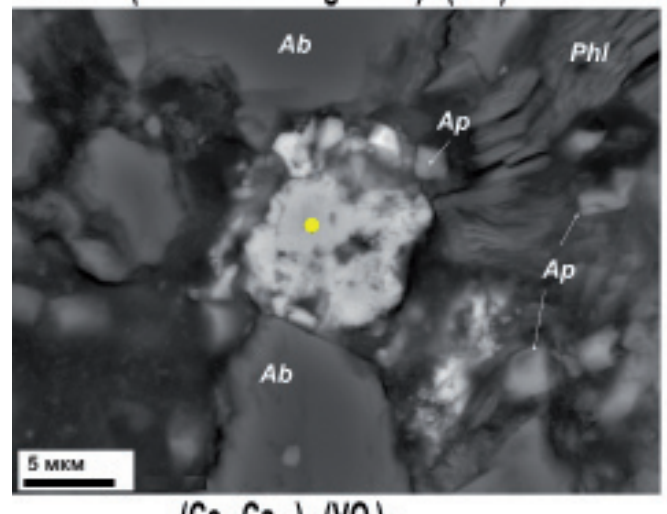

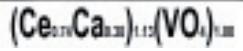

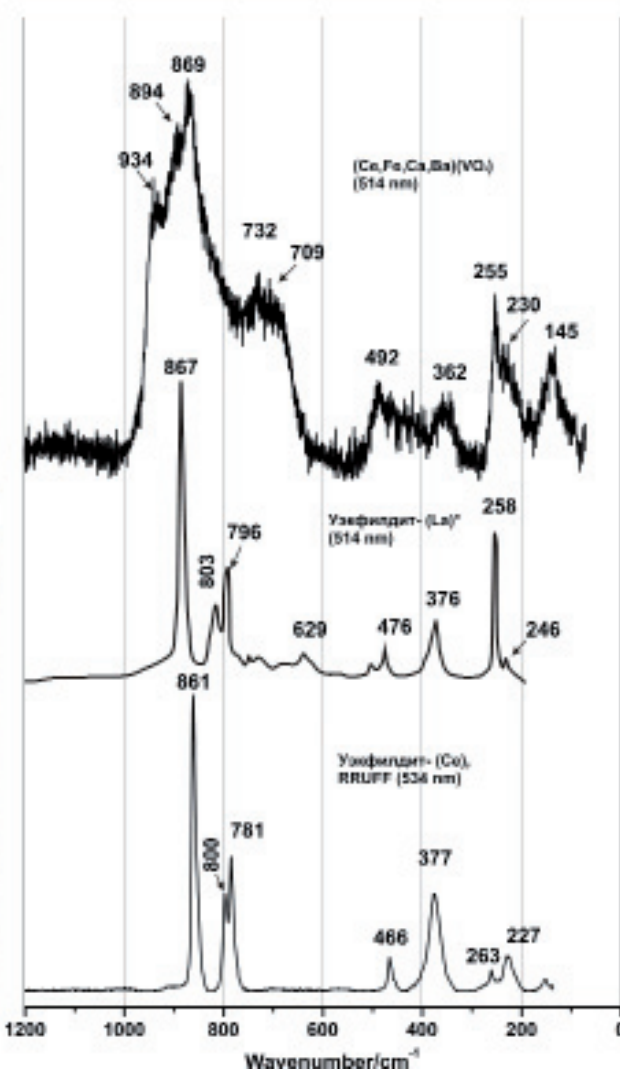

Рис.4. Характер выделений уэкфилдита-Се (слева - снимки BSE) и его раман-спектр в с в сравнении со спектрами уэкфилдита-(La) и уэкфилдита-(Ce) из базы RRUFF (справа). Химический состав представлен в виде кристаллохимических формул. Аb - альбит; $\mathrm{Phl}$ - флогопит; Ap - апатит.

не имеющих на настоящий момент статуса минерального вида. Выделения минерала мелкие размером в несколько микрон (рис. 4). Его состав, оцененный по нескольким зернам отвечает составу редкоземельного ванадата - уэкфилдиту-(Се). Его структурное состояние было определено методом KP. Раман-спектр минерала в целом соответствует спектрам, приведенным в базе RRUFF для минералов этого вида. Некоторая размазанность спектра объясняется тем, что зерно, по которому были выполнены КР исследования, обрастает по краям ванадатом бария из группы бракебушита. Ввиду мелких размеров фаз происходит наложение спектров.

Большая группа новых для региона и России минералов была открыта в образцах, отобранных из кварц - карбонатных жил (Pb-Zn) Мурманского побережья. Образцы отбирались из отвалов старых выработок и обнажений в сентябре прошлого года. В четвертой декаде прошлого года (октябрь-декабрь) был проведен рентгенофазовый анализ вторичных минералов. В результате было выявлено несколько новых для региона видов, относимых к классам водных карбонатов, сульфатов и минералов класса органических соединений.

Гидроцинкит $\mathrm{Zn}_{5}\left(\mathrm{CO}_{3}\right)_{2}(\mathrm{OH})$. Минерал бледно-желтого, белого цвета, в виде порошковатых агрегатов в смеси с гемиморфитом в ассоциации с малахитом и сфалеритом. Рентгеноструктурный анализ методом порошка показал принадлежность минерала к этому виду (рис. 5.).

Aypuхальцит $(\mathbf{Z n}, \mathbf{C u})_{5}\left(\mathrm{CO}_{3}\right)_{2}(\mathrm{OH})_{6}$ Минерал бледно-зелёного с голубоватым оттенком цвета в виде чешуйчатых листоватых агрегатов выполняет трещины в сфалерите. Рентгеноструктурный анализ методом порошка показал идентичность спектра отражений с эталонной рентгенограммой аурихальцита в базе ICDC2 (рис. 6).

Лангит $\mathrm{Cu}_{4}\left(\mathrm{SO}_{4}\right)(\mathrm{OH})_{6} \cdot 2 \mathrm{H}_{2} \mathrm{O}$. Минерал синего, сине-зеленого цвета в виде мелких пластинчатых кристаллов образующих корки на поверхности других медных минералов: малахита, брошантита. Рентгенограммы порошка наших образцов и образца из базы данных ICDC идентичны (рис. 7). 

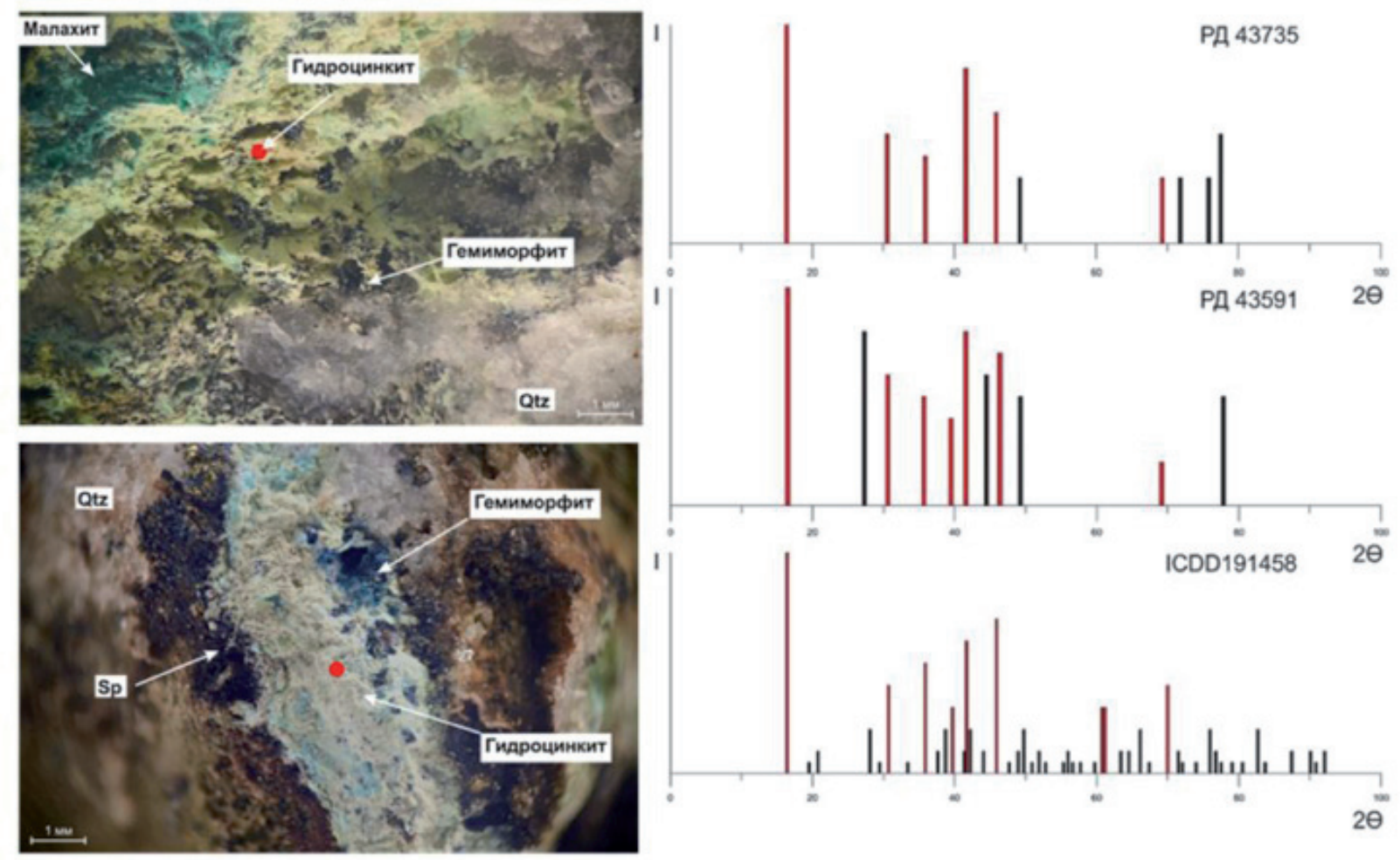

Рис. 5. Фотографии образцов (слева) и столбиковые диаграммы рентгенограмм порошка гидроцинкита в сравнении с эталонной рентгенограммой. Qtz - кварц; Sp - сфалерит.
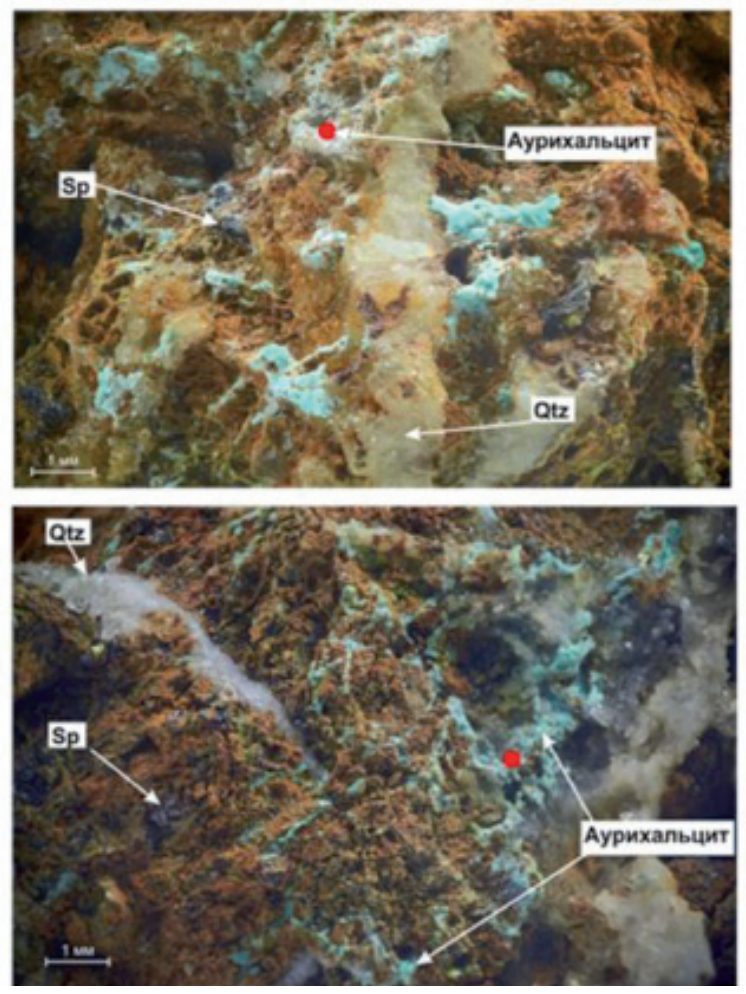
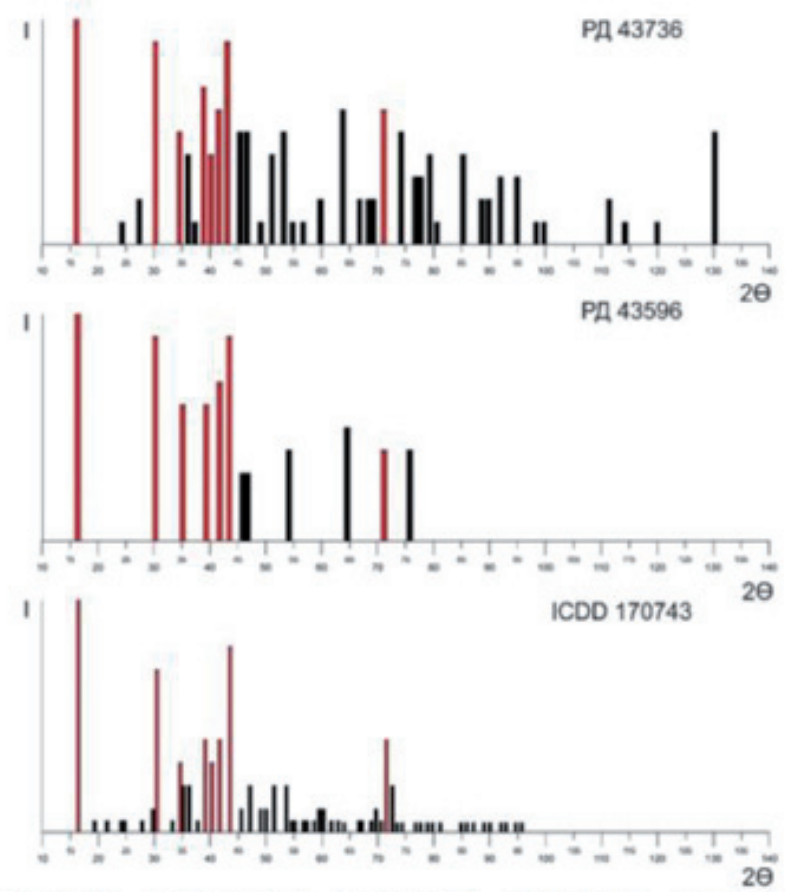

$\mathrm{D}(\mathrm{A})($ ) : 6.78 (10), 3.68 (7), 2.89 (4), 2.72 (4), 2.61 (8), 1.827 (4), 1.656 (4)

Рис. 6. Фотографии образцов (слева) и столбиковые диаграммы рентгенограмм порошка аурихальцита в сравнении с эталонной рентгенограммой. Qtz - кварц; Sp - сфалерит. 

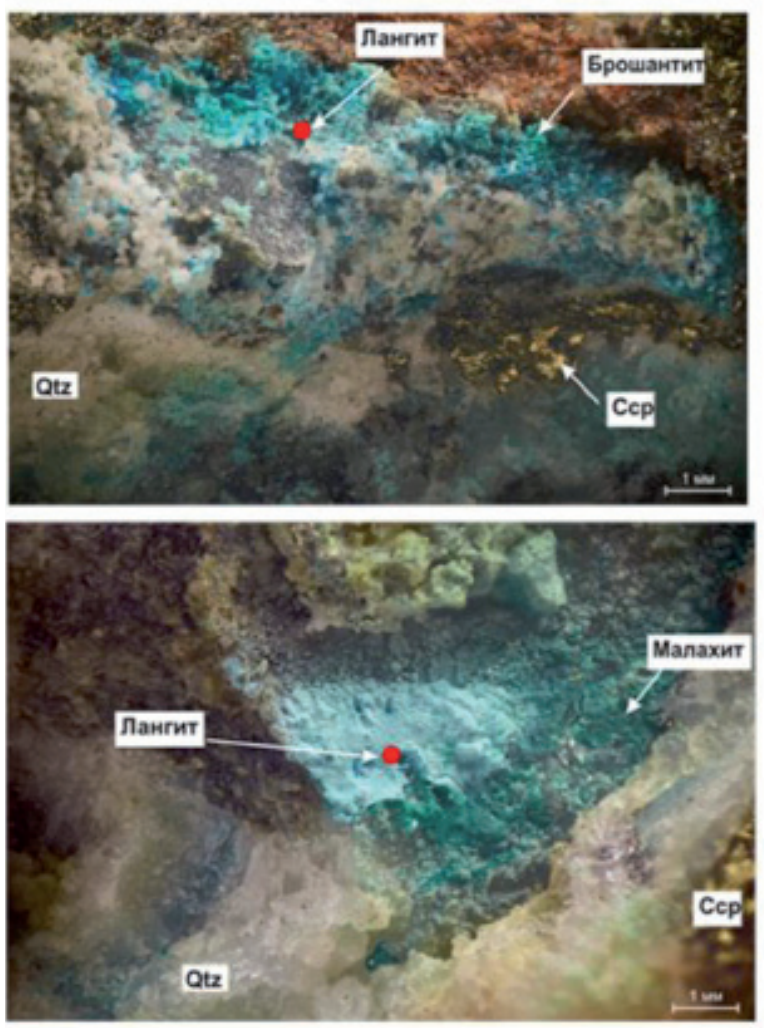
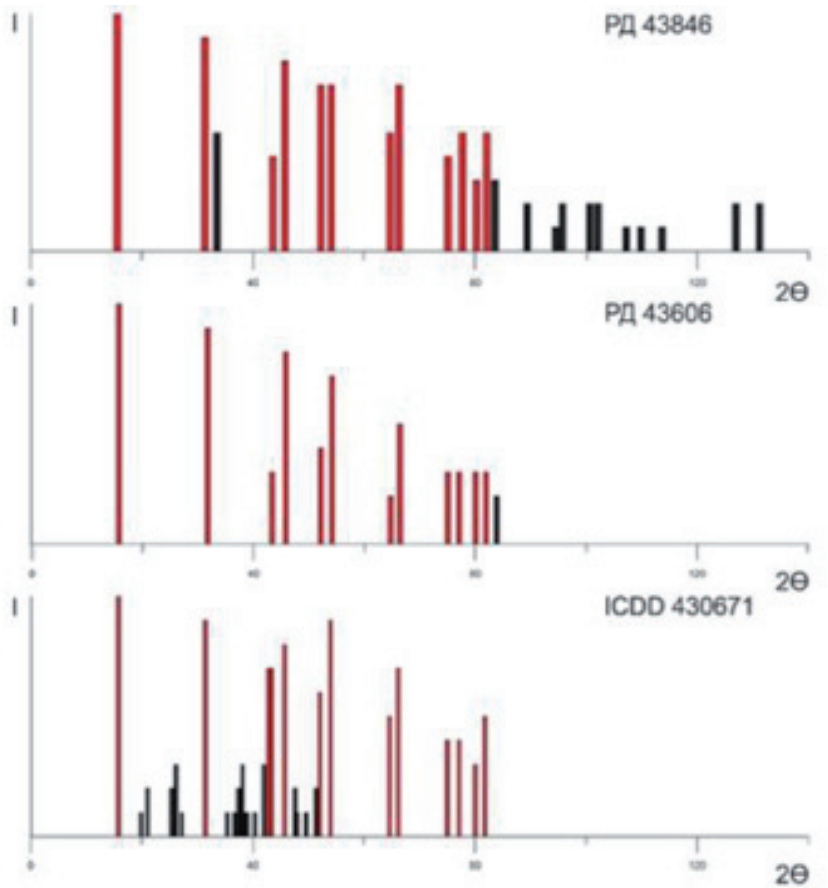

$\mathrm{D}(\AA)(l): 7.063(10), 3.567(9), 2.662(7)$ $2.616(7), 2.493(8), 2.134(9), 1.773(7)$

Рис. 7. Фотографии образцов (слева) и столбиковые диаграммы рентгенограмм порошка лангита в сравнении с эталонной рентгенограммой. Qtz - кварц; Ccp - халькопирит.

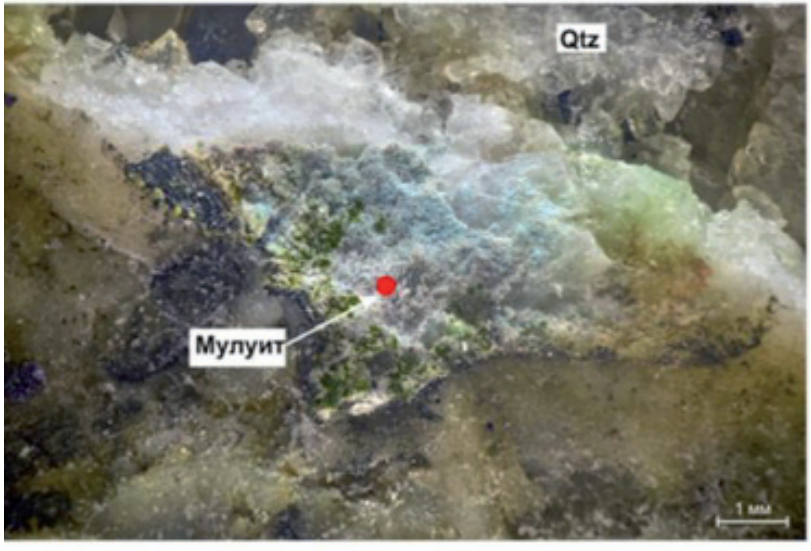

$D(A)(l): 3.895(10), 2.484(3)$

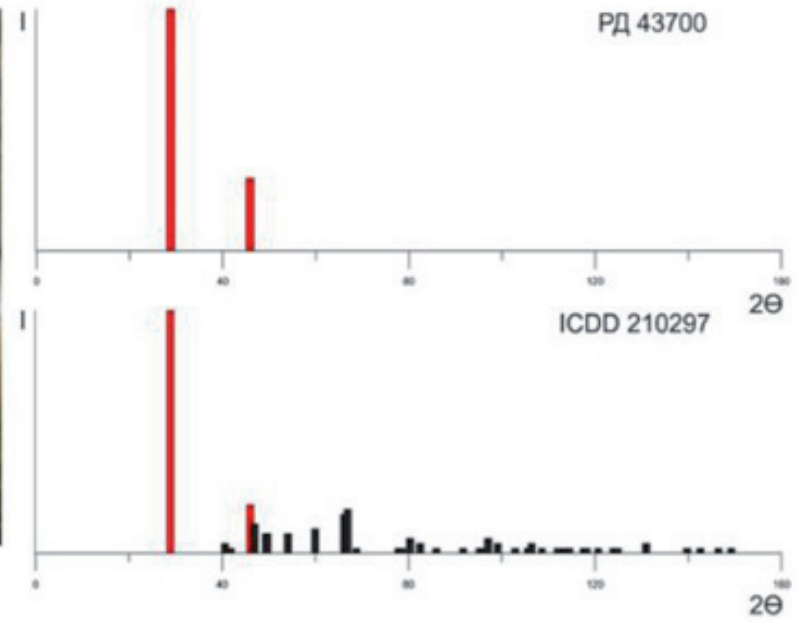

Рис. 8. Макрофото образца (слева) и столбиковые диаграммы рентгенограмм порошка лангита в сравнении с эталонной рентгенограммой. Qtz - кварц.

Следующая группа минералов, которые согласно современной номенклатуре минералов, относятся к классу органических веществ - оксалатам, солям щавелевой кислоты.

Myлуиm $\boldsymbol{C u}_{2} \boldsymbol{O}_{4} \cdot \boldsymbol{n} \boldsymbol{H}_{2} \boldsymbol{O}$ образует сноповидные агрегаты, корки белого светло-серого цвета, состоящие из тонко призматических и игольчатых кристаллов в пустотах среди кварца. Рентгенограмма порошка данного минерала показала идентичность эталонной рентгенограмме мулуита (водного оксалата меди) (рис. 8).

Уэдделлит $\mathrm{CaC}_{2} \mathrm{O}_{4} \cdot 2 \mathrm{H}_{2} \mathrm{O}$ - водный оксалат кальция представлен в виде тонкозернистых корок, состоящих из уплощенно-дипирамидальных прозрачных кристаллов, окрашенных в салатовый 

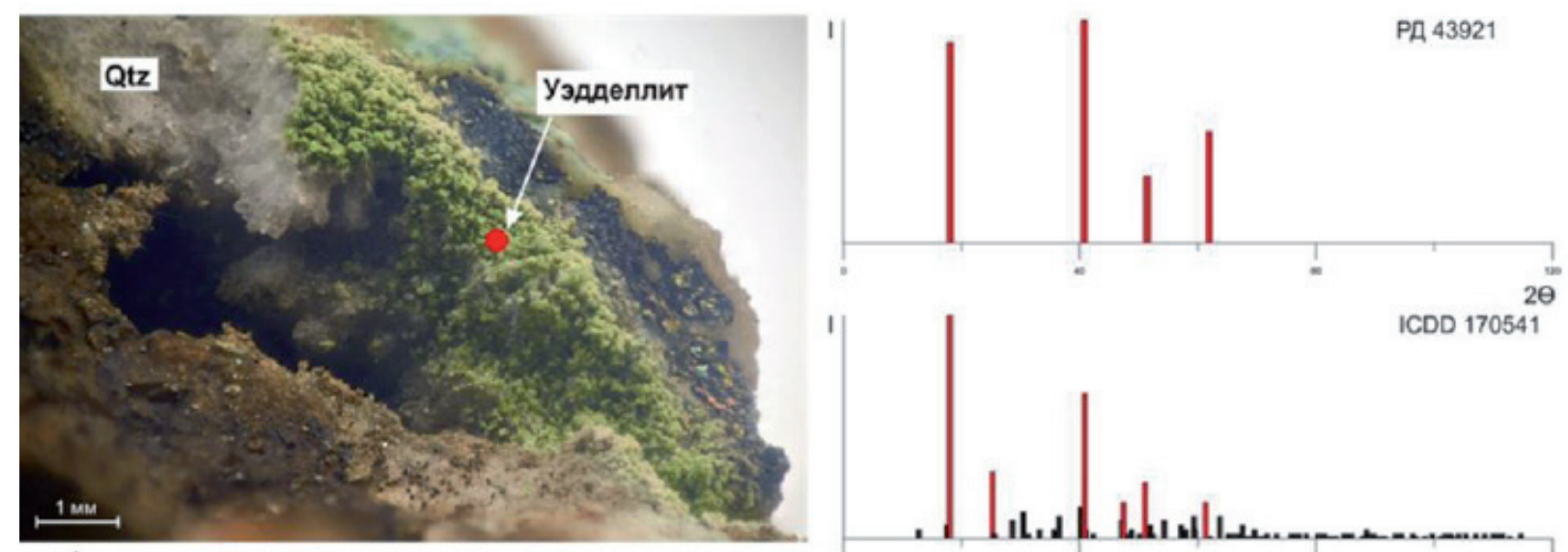

$\mathrm{D}(\mathrm{A})(I): 6.16(9), 2.78(10), 2.23(3), 1.88(5)$

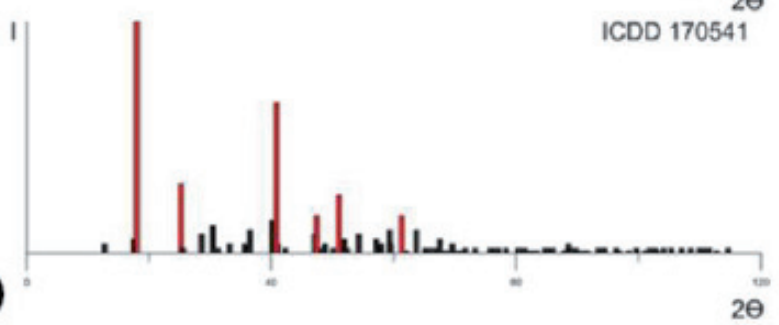

Рис. 9. Макросъемка образца (слева) и столбиковые диаграммы рентгенограмм порошка уэдделлита в сравнении с эталонной рентгенограммой. Qtz - кварц.

цвет в полости кварца. Рентгеноструктурный анализ методом порошка показал идентичность спектра отражений с эталонной рентгенограммой уэдделлита.

Таким образом, на изученных объектах достоверно установлено восемь минеральных видов, из которых три минерала являются первыми находками для региона и пять впервые обнаруженными в России.

Работа выполнена в рамках темы НИР ГИ КНЦ РАН № 0231-2015-0001.

\section{Литература}

1. Волошин А.В., Компанченко А.А., Карпов С.М., Борисова В.В. Новые данные о минералах. Вып. 3. Первые находки в России и Кольском регионе // Труды ХІІ ФНС. Апатиты: Изд-во К \& M, 2017. С. 244-250.

2. Юшкин Н.П. Минералогия на пороге нового тысячелетия // Уральский минералогический сборник. Миасс: ИМин УрО РАН. 1999. №9. С. 3-21.

3. Mellini M., Merlino S., Orlandi P., Rinaldi R. Cascandite and jervisite, two new silicates from Baveno, Italy// Am. Min.. 1982. V. 67. P. 599-603.

4. Neves J.M.C., Nunes J.E.L. High hafnium members of the zircon-hafnon series from the granite pegmatites of Zambezia, Mozambique // Contrib. Miner. Petrol. 1974. V. 48. P. 73-80.

5. Potter E.G., Mitchell R.H. Mineralogy of the Deadhorse Creek volcaniclastic breccias complex, northwestern Ontario, Canada // Contrib. Miner. Petrol. 2005. V. 150. P. 212-229.

6. Yin R., Wang R.C., Zhang A-C. et al. Extreme fractionation from zircon to hafnon in the Koktokay No. 1 granitic pegmatite, Altai, northwestern China // Am. Miner. 2013. V. 98. P. 1714-1724. 